Molecules 2003, 8, 614-621

molecules

ISSN 1420-3049

http://www.mdpi.org

\title{
Constituents from Moghat, the Roots of Glossostemon bruguieri (Desf.)
}

\author{
Meselhy R. Meselhy *
}

Department of Pharmacognosy, Faculty of Pharmacy, Cairo University, Cairo 11562, Egypt, Tel:

(+20) 2-3624105, Fax: (+20) 2-3635140.

* To whom correspondence should be addressed; e-mail: meselhyragab@yahoo.com

Received: 10 March 2003; in revised form: 27 May 2003 / Accepted: 25 July 2003 / Published: 31 July 2003

\begin{abstract}
The new biflavone moghatin (3"'-hydroxycupressuflavone) was isolated from Moghat, the dried peeled roots of Glossostemon bruguieri (Desf.), together with five known compounds: 4'-methoxyisoscutellargin, sesamin, chrysophanol, emodin and methoxyemodin (physcion). The structures of these compounds were assigned on the basis of spectroscopic data. Occurrence of these compounds in Moghat is reported here for the first time.
\end{abstract}

Keywords Moghat, Glossostemon bruguieri, Sterculiaceae, biflavone, anthraquinone.

\section{Introduction}

Plants of the cacao family (Sterculiaceae) are trees, shrubs, or herbs comprising about 65 genera and 1,000 species that are further characterized by the presence of stellate hairs and, in most cases, mucilaginous sap [1]. Glossostemon bruguieri (Desf.), family Sterculiaceae, is a shrub with thick long tapering dark colored roots $(70-100 \mathrm{~cm}$ in length and $5-8 \mathrm{~cm}$ in breadth) $[1,2]$. G. bruguieri is native to Iraq and Iran, and was cultivated in Egypt for its edible roots a long time ago. The dried peeled roots of G. bruguieri (Desf.) (known in Arabic as Moghat) are used in folk medicine for the treatment of gout and spasms, and as a tonic and nutritive agent [3]. After childbirth, women have especially used hot drinks of powdered Moghat as a general tonic and lactagogue. Due to its high content of mucilage (up to $27 \%$ based on dry weight) [2, 4-6], Moghat is also prescribed as a demulcent agent. Previous work 
on the chemistry of the compounds produced from Moghat indicated the presence of oestrone [2,7], scopoletin, phytosterols (a mixture of $\beta$-sitosterol, stigmasterol and campesterol) $[2,8], \alpha$-amyrin, and glucosides of flavone and chalcone [2]. In addition, amino acids and fatty acids were identified [2,4]. We report herein the isolation and structure elucidation of six compounds from Moghat roots.

\section{Results and Discussion}

Fractionation and repeated chromatography of the $\mathrm{MeOH}$ extract of Moghat roots has led to the isolation of six compounds (1-6) (Figure 1).

\section{Figure 1}<smiles>[R]c1cc(-c2cc(=O)c3c(O)cc(O)c(-c4c(O)cc(O)c5c(=O)cc(-c6ccc(O)cc6)oc45)c3o2)ccc1O</smiles>

Cupressuflavone $\mathrm{R}=\mathrm{H}$<smiles>O=c1cc(-c2ccc(O)cc2)oc2c(-c3c(O)cc(O)c4c(=O)cc(-c5ccc(O)cc5)oc34)c(O)cc(O)c12</smiles>

Agathisflavone<smiles>c1cc2c(cc1[C@H]1OC[C@@H]3[C@H](c4ccc5c(c4)OCO5)OC[C@H]13)OCO2</smiles><smiles>[R]c1cc(O)c2c(c1)C(=O)c1cc(C)cc(O)c1C2=O</smiles>

$3 \mathrm{R}=\mathrm{H}$

$4 \mathrm{R}=\mathrm{OH}$

$5 \mathrm{R}=\mathrm{OMe}$<smiles>[R4]c1ccc(-c2cc(=O)c3c(O)cc(O)c([R1])c3o2)cc1[R4]</smiles>

$2 \mathrm{R}_{1}=\mathrm{OH}, \mathrm{R}_{2}=\mathrm{OMe}, \mathrm{R}_{3}=\mathrm{H}$ Apigenin $\mathrm{R}_{1}=\mathrm{H}, \mathrm{R}_{2}=\mathrm{OH}, \mathrm{R}_{3}=\mathrm{H}$ Luteolin $\mathrm{R}_{1}=\mathrm{H}, \mathrm{R}_{2}=\mathrm{R}_{3}=\mathrm{OH}$

Compounds 2-6 were previously obtained from natural sources and they were identified as 4'-methoxyisoscutellargin (2) [9,10], chryophanol (3) [11], emodin (4) [12], methoxyemodin 
(physcion) (5) [11], and sesamin (6) $[13,14]$, respectively, by comparing their physical and spectral data with those reported. Compound $\mathbf{1}$ is a new natural product and its structure was determined as follows.

Compound 1 was obtained as a yellow amorphous powder that gave a positive magnesiumhydrochloric acid reaction for flavonoids. Its UV spectrum showed absorption bands at 262 and 332 $\mathrm{nm}$, characteristic for flavones. The IR spectrum showed absorptions for hydroxyl $\left(3440 \mathrm{~cm}^{-1}\right), \alpha, \beta-$ unsaturated $\mathrm{C}=\mathrm{O}\left(1640 \mathrm{~cm}^{-1}\right)$ and aromatic $\left(1610\right.$ and $\left.1580 \mathrm{~cm}^{-1}\right)$ functions. Compound 1 was assigned the molecular formula $\mathrm{C}_{30} \mathrm{H}_{18} \mathrm{O}_{11}$ by EI-MS $\left(\mathrm{m} / z 555[\mathrm{M}+\mathrm{H}]^{+}\right)$, which suggested the presence of a biflavonoid structure. Examination of the ${ }^{1} \mathrm{H}-\mathrm{NMR}$ spectrum of $\mathbf{1}$ (see Experimental) with the aid of ${ }^{1} \mathrm{H}-{ }^{1} \mathrm{H}$ COSY and HMQC experiments indicated that $\mathbf{1}$ is a biflavone composed of two asymmetric units, an apigenin moiety (I) [two doublets (each $2 \mathrm{H}, J=8.7 \mathrm{~Hz}$ ) at $\delta 6.89$ and 8.02, and two singlets at $\delta 6.27$ and 6.79] and a luteolin moiety (II) [three proton signals at $\delta 6.93$ (d, $J=8.4 \mathrm{~Hz}$ ), 7.44 (d, $J=2.2$ $\mathrm{Hz}$ ) and $7.53(\mathrm{dd}, J=2.2$ and $8.4 \mathrm{~Hz}$ ), and two singlets at $\delta 6.28$ and 6.67].

Table 1. ${ }^{13} \mathrm{C}-\mathrm{NMR}$ spectral data of $\mathbf{1}$, related flavones and biflavones

\begin{tabular}{c|c|l|l|l|l}
\hline \hline $\begin{array}{c}\text { Carbon } \\
\text { No. }\end{array}$ & $\mathbf{1}$ & Apigenin $^{*}$ & Luteolin $^{*}$ & Cupressuflavone $^{\#}$ & Agathisflavone $^{\#}$ \\
\hline $2\left(2^{\prime \prime}\right)$ & $164.4(164.4)$ & 164.1 & $164.5^{\mathrm{a}}$ & $163.9(163.9)$ & $163.9^{\mathrm{a}}(164.1)^{\mathrm{a}}$ \\
$3\left(3^{\prime \prime}\right)$ & $102.9(102.8)$ & 102.8 & 103.3 & $102.8(102.8)$ & $102.8^{\mathrm{b}}(103.1)^{\mathrm{b}}$ \\
$4\left(4^{\prime \prime}\right)$ & $182.1(182.0)$ & 181.8 & 182.2 & $182.1(182.1)$ & $182.1^{\mathrm{c}}(182.3)^{\mathrm{c}}$ \\
$5\left(5^{\prime \prime}\right)$ & $164.1(164.1)$ & 157.3 & 157.9 & $161.3(161.3)$ & $160.9(160.0)$ \\
$6\left(6^{\prime \prime}\right)$ & $99.8(99.7)$ & 98.8 & 99.2 & $99.0(99.0)$ & $98.9(103.6)^{\mathrm{d}}$ \\
$7\left(7^{\prime \prime}\right)$ & $164.4(164.4)$ & 163.7 & $164.7^{\mathrm{a}}$ & $162.7(162.7)$ & $162.7^{\mathrm{e}}(162.9)^{\mathrm{e}}$ \\
$8\left(8^{\prime \prime}\right)$ & $104.2(104.2)$ & 94.0 & 94.2 & $98.7(98.7)$ & $99.4(93.7)$ \\
$9\left(9^{\prime \prime}\right)$ & $157.1(157.1)$ & 161.5 & 162.1 & $155.3(155.3)$ & $155.1^{\mathrm{f}}(157.0)^{\mathrm{f}}$ \\
$10\left(10^{\prime \prime}\right)$ & $104.2(104.2)$ & 103.7 & 104.2 & $104.3(104.3)$ & $104.0^{\mathrm{d}}(103.8)^{\mathrm{d}}$ \\
$1^{\prime}\left(1^{\prime \prime \prime}\right)$ & $121.9(121.5)$ & 121.3 & 119.3 & $121.7(121.7)$ & $121.7^{\mathrm{g}}(121.5)^{\mathrm{g}}$ \\
$2^{\prime}\left(2^{\prime \prime \prime}\right)$ & $128.9(114.2)$ & 128.4 & 113.8 & $127.9(127.9)$ & $128.2^{\mathrm{h}}(128.6)^{\mathrm{h}}$ \\
$3^{\prime}\left(3^{\prime \prime \prime}\right)$ & $115.9(145.8)$ & 116.0 & 146.2 & $116.1(116.1)$ & $116.2(116.2)$ \\
$4^{\prime}\left(4^{\prime \prime \prime}\right)$ & $161.5(149.8)$ & 161.1 & 150.1 & $161.1(161.1)$ & $161.2(161.3)$ \\
$5^{\prime}\left(5^{\prime \prime \prime}\right)$ & $115.9(116.1)$ & 116.0 & 116.4 & $116.1(116.1)$ & $116.2(116.2)$ \\
$6^{\prime}\left(6^{\prime \prime \prime}\right)$ & $128.9(119.6)$ & 128.4 & 121.7 & $127.9(127.9)$ & $128.2^{\mathrm{k}}(128.6)^{\mathrm{k}}$ \\
\hline \hline
\end{tabular}

Data marked $^{\#}$ are taken from ref. [15] and those marked * from ref. [16].

Assignments with the same superscript in the same column may be reversed.

When the ${ }^{13} \mathrm{C}-\mathrm{NMR}$ shift values of $\mathbf{1}$ were compared with those of related biflavones [15] and flavones [16], the involvement of C-8 and C-8" in the interflavone linkage of the two asymmetric moieties in 1 was suggested (Table 1). Thus, when compared with monomeric flavones with a 5,7- 
dihydroxy substitution [15], the C-8 carbons in both moieties were found to be shifted downfield (+ $10.0 \mathrm{ppm})$, whereas the carbon atoms C-6 and C-6" in 1 resonate at almost identical chemical shift values ( $\delta 99.8$ and 99.7, respectively) for the respective carbon atoms as seen in monomers. Involvement of C-8 and C-8" in an interflavonoid linkage was previously reported for cupressuflavone (Table 1), a symmetrical C-8, C-8" biapigenin, previously isolated from Cupressus obtusa [15]. This finding was further supported by a HMBC experiment. Long-range correlation between the ${ }^{1} \mathrm{H}$ signals at $\delta 6.27$ and 6.28 (H-6 and H-6", respectively) and the ${ }^{13} \mathrm{C}$ signal at $\delta 104.2$ was observed. This ${ }^{13} \mathrm{C}$ signal showed also long range correlation with ${ }^{1} \mathrm{H}$ signals at $\delta 6.67$ and $6.79\left(\mathrm{H}-3^{\prime \prime}\right.$ and $\mathrm{H}-3$, respectively). The structure of $\mathbf{1}$ was, therefore, determined to be a $3^{\prime \prime \prime}$-hydroxy derivative of cupressuflavone and was given the name moghatin.

\section{Conclusions}

In addition to mucilage, oestrone and phytosterol, the present study provides the first report on the presence of biflavones, methoxylated flavones, anthraquinones and lignans in Moghat. These constituents exhibit a variety of biological effects. Besides, sesamin has been found to be good for the liver, and has antihypertensive effects [17]. This broad spectrum of constituents suggests the possible utilization of Moghat as a valuable crude drug.

\section{Acknowledgments}

The author is grateful to Prof. Dr. Samia Abdel-Wahab, Professor of Applied Pharmacognosy, Faculty of Pharmacy, Cairo University, Prof. Dr. Masao Hattori, director of the Institute of Natural Medicine INM), Toyama Medical and Pharmaceutical University, and to Dr. Katuoko Komatsu of the Research Center of Ethnomedicines, INM, for providing NMR facilities and for their support.

\section{Experimental}

\section{General}

Optical rotations were measured with a Jasco DIP-360 automatic polarimeter. UV spectra were measured with a Shimadzu UV-VIS recording spectrophotmeter. ${ }^{1} \mathrm{H}$ - and ${ }^{13} \mathrm{C}-\mathrm{NMR}$ spectra were measured with a Jeol JNA-LA 400WB-FT spectrometer $\left({ }^{1} \mathrm{H}\right.$ at $400 \mathrm{MHz},{ }^{13} \mathrm{C}$ at $\left.100 \mathrm{MHz}\right)$, the chemical shifts being reported in ppm with TMS as an internal standard. Electron impact (EI) mass spectra were measured with a Jeol JMS-AX 505 HAD mass spectrometer at an ionization voltage of 70 $\mathrm{eV}$. 


\section{Plant Material}

The air-dried peeled roots of G. bruguieri (Desf.), family Sterculiaceae, were purchased from Harraz drugstore in Cairo in March 2001. The plant material was kindly identified by Prof. Dr. ElSayed A. Aboutabl, Professor of Pharmacognosy, Faculty of Pharmacy, Cairo University, and a voucher specimen was deposited in the museum of the Department of Pharmacognosy of this university.

\section{Extraction and Isolation}

Commercially available Moghat (900 g) was pulverized and extracted with portions of $\mathrm{MeOH}$ under reflux ( $2 \mathrm{~L}$ x 4, $2 \mathrm{~h}$ each). The $\mathrm{MeOH}$ solutions were combined and evaporated under reduced pressure to give $75 \mathrm{~g}$ of a viscous residue. This residue was again dissolved in $\mathrm{MeOH}(500 \mathrm{~mL})$ under sonication and $\mathrm{H}_{2} \mathrm{O}(500 \mathrm{~mL})$ was added. The organic solvent was evaporated under reduced pressure and the suspension was applied to a column of Diaion HP-20 (1 L). The column was washed with $\mathrm{H}_{2} \mathrm{O}$ $(4 \mathrm{~L}), \mathrm{MeOH}(3 \mathrm{~L})$ and finally with $\mathrm{CHCl}_{3}(3 \mathrm{~L})$. The $\mathrm{MeOH}$ and $\mathrm{CHCl}_{3}$ eluates were separately evaporated to dryness to give $37.5 \mathrm{~g}$ and $20 \mathrm{~g}$ of oily residues, respectively. The residue from the $\mathrm{MeOH}$ eluate was suspended in $\mathrm{MeCN}_{-} \mathrm{H}_{2} \mathrm{O}(9: 1 \mathrm{v} / \mathrm{v}, 500 \mathrm{~mL})$ and partitioned with n-hexane $(500 \mathrm{~mL}$ $\mathrm{x}$ 4) to give an MeCN-sol. fraction and a hexane-sol. fraction. The MeCN-soluble fraction was evaporated to give $9.4 \mathrm{~g}$ of a dry residue. This residue was chromatographed on a column of reversed phase silica gel (RP-18, $32 \times 4 \mathrm{~cm}$, i.d.). Elution was started with $\mathrm{MeOH}-\mathrm{H}_{2} \mathrm{O}(3: 7 \mathrm{v} / \mathrm{v}, 200 \mathrm{~mL})$, and then with $10 \%$ increments of $\mathrm{MeOH}$ [100 fractions (15 mL each) were collected]. Fractions 3 and 4 were pooled and evaporated to give a residue $(670 \mathrm{mg})$. This residue was chromatographed on a Sephadex LH-20 column $\left(20 \times 2 \mathrm{~cm}\right.$, i.d.) with EtOH $-\mathrm{H}_{2} \mathrm{O}(3: 7 \mathrm{v} / \mathrm{v})$ elution and $20 \mathrm{~mL}$ subfractions were collected to give compound 1 (35 mg) from subfractions 9 and 10 .

Compound 2 (83 $\mathrm{mg}$ ) was obtained as a light yellow amorphous powder from fractions 5-11 after crystallization of the crude isolate $(120 \mathrm{mg})$ from $\mathrm{MeOH}$.

The residue from the $\mathrm{CHCl}_{3}$ eluate was similarly suspended in $\mathrm{MeCN}-\mathrm{H}_{2} \mathrm{O}(9: 1 \mathrm{v} / \mathrm{v}, 400 \mathrm{~mL})$, and partitioned with n-hexane $\left(400 \mathrm{~mL}\right.$ x 4). After evaporation, an $\mathrm{MeCN}$-sol. fraction $(2.8 \mathrm{~g})$ of the $\mathrm{CHCl}_{3}$ eluate was obtained. This residue was chromatographed on a column of silica gel $(30 \times 3.5 \mathrm{~cm}$, i.d.). After the column was washed with n-hexane $(1 \mathrm{~L})$, elution was started with $2 \%$ increment of acetone in n-hexane $(250 \mathrm{~mL}$ each), and 60 fractions (each of $15 \mathrm{~mL}$ ) were obtained. Fractions 2-7 (1.2 g, eluted with $2 \%$ acetone in $n$-hexane) was chromatographed on a column of silica gel $(20 \times 2 \mathrm{~cm}$, i.d.) eluting with n-hexane $(50 \mathrm{~mL})$, and then successively with $200 \mathrm{~mL}$ of n-hexane-EtOAc $(8: 2$ and then 6:4 v/v). The fractions eluted with n-hexane-EtOAc $(20 \mathrm{mg})$ were pooled and applied to a column of reversed phase silica gel (RP-18, 20 x $1.5 \mathrm{~cm}$, i.d.). Elution with $\mathrm{MeCN}_{-} \mathrm{H}_{2} \mathrm{O}(9: 1 \mathrm{v} / \mathrm{v})$ gave 5 (physcion, $8 \mathrm{mg}$ ) as fine orange needles $(\mathrm{MeOH})$ from subfractions 4 and 5, while subfraction 7 gave 3 (chrysophanol, 7 $\mathrm{mg}$ ) as orange needles from a hexane-acetone mixture. On concentration, fractions 36-39 (eluted with $6 \%$ acetone in n-hexane) gave 6 (sesamin, $21 \mathrm{mg}$ ) as colorless prisms from n-hexane-acetone mixture. Fractions 49-56 (eluted with 6-8\% acetone in n-hexane, $20 \mathrm{mg}$ ) was further purified by MPLC 


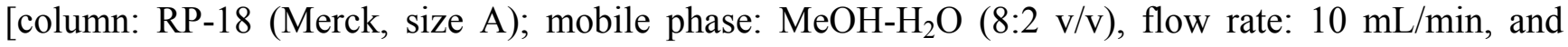
fractions of $10 \mathrm{~mL}$ were collected] to give 4 (emodin, $8 \mathrm{mg}$ ) from subfractions $9-12$ as fine orange crystals from n-hexane.

Moghatin (1): Yellow amorphous powder; $[\alpha]_{\mathrm{D}}+2.0^{\circ}\left(\mathrm{MeOH}, c\right.$ 0.1); UV $\lambda_{\max }(\log \varepsilon): 262$ (4.2), 330 (4.1) nm; IR $v_{\max }(\mathrm{KBr}): 3440,1640,1610,1580,1165 \mathrm{~cm}^{-1}$; EI-MS: $m / z 555[\mathrm{M}+\mathrm{H}]^{+}, 428,354,280$, 206; ${ }^{1} \mathrm{H}-\mathrm{NMR}\left(\mathrm{DMSO}-d_{6}\right)$ $\delta: 6.27$ (1H, s, H-6), 6.28 (1H, s, H-6"), 6.67 (1H, s, H-3"), 6.79 (1H, s, H3), $6.89\left(2 \mathrm{H}, \mathrm{d}, J=8.7 \mathrm{~Hz}, \mathrm{H}-3^{\prime}\right.$ and H-5'), $6.93\left(1 \mathrm{H}, \mathrm{d}, J=8.4 \mathrm{~Hz}, \mathrm{H}-5^{\prime \prime \prime}\right), 7.44$ (1H, d, $J=2.2 \mathrm{~Hz}, \mathrm{H}-$ $\left.2^{\prime \prime \prime}\right), 7.53\left(1 \mathrm{H}, \mathrm{dd}, J=2.2\right.$ and $\left.8.4 \mathrm{~Hz}, \mathrm{H}-6^{\prime \prime \prime}\right)$, and $8.02\left(2 \mathrm{H}, \mathrm{d}, J=8.7 \mathrm{~Hz}, \mathrm{H}-2^{\prime}\right.$ and $\left.\mathrm{H}-6^{\prime}\right)$; ${ }^{13} \mathrm{C}-\mathrm{NMR}$ $\left(\mathrm{DMSO}-d_{6}\right)$ 8: 99.7 (C-6"), 99.8 (C-6), 102.8 (C-3"), 102.9 (C-3), 104.2 (C-8, C-8", C-10, and C-10"), 114.2 (C-2"'), $115.9\left(\mathrm{C}-3^{\prime}\right), 116.1$ (C-5'"'), 119.6 (C-6"'), 121.5 (C-1'"'), $121.9\left(\mathrm{C}-1^{\prime}\right), 128.9$ (C-2'), 145.8 (C-3'"'), 149.8 (C-4"'), 157.1 (C-9, C-9"), 161.5 (C-4'), 164.1 (C-5, C-5"), 164.4 (C-2, C-2", C-7, C-7"), $182.0\left(\mathrm{C}-4^{\prime \prime}\right)$, and 182.1 (C-4).

4'-Methoxyisoscutellargin (2): Light yellow amorphous powder; UV $\lambda_{\max }(\log \varepsilon): 270$ (2.8), 300 (2.1, sh), 326 (3.2), $360(2.3, \mathrm{sh}) \mathrm{nm}$; IR $v_{\max }(\mathrm{KBr}): 3420,1660,1610,1580 \mathrm{~cm}^{-1}$; EI-MS: $\mathrm{m} / z 300[\mathrm{M}]^{+}$, $285\left[\mathrm{M}-\mathrm{CH}_{3}\right]^{+}, 206,193,177,133\left[\left(\mathrm{M}-\mathrm{C}_{9} \mathrm{H}_{9} \mathrm{O}\right)+\mathrm{H}\right]^{+}, 94 ;{ }^{1} \mathrm{H}-\mathrm{NMR}\left(\mathrm{DMSO}-d_{6}\right) \delta: 3.84\left(3 \mathrm{H}, \mathrm{s},-\mathrm{OC}_{3}\right)$, $6.28(1 \mathrm{H}, \mathrm{s}, \mathrm{H}-6), 6.84(1 \mathrm{H}, \mathrm{s}, \mathrm{H}-3), 7.10\left(2 \mathrm{H}, \mathrm{d}, J=8.7 \mathrm{~Hz}, \mathrm{H}-3^{\prime}\right.$ and H-5'), 8.09 (2H, d, J=8.7 Hz, H$2^{\prime}$ and $\left.\mathrm{H}-6^{\prime}\right), 9.93(1 \mathrm{H}$, br s, $-\mathrm{OH})$, and $12.68\left(1 \mathrm{H}\right.$, br s, OH) ${ }^{13} \mathrm{C}-\mathrm{NMR}\left(\mathrm{DMSO}-d_{6}\right) \delta: 55.5\left(-\mathrm{OCH}_{3}\right)$, 99.5 (C-6), 103.2 (C-3), 103.9 (C-10), 114.5 (C-3' and C-5'), 121.1 (C-8), 122.9 (C-1'), 128.5 (C-2' and C-6'), 149.7 (C-9), 156.9 (C-5), 157.0 (C-7), 162.4 (C-4'), 163.4 (C-2), and 181.9 (C-4).

Chrysophanol (3): Orange needles, m.p. 197-199 ${ }^{\circ} \mathrm{C}$ (lit.[18] m.p. $196^{\circ} \mathrm{C}$ ); EI-MS: $m / z 254$ [M] $]^{+}$; ${ }^{1} \mathrm{H}-\mathrm{NMR}\left(\mathrm{CDCl}_{3}\right) \delta: 2.46\left(3 \mathrm{H}, \mathrm{s}, \mathrm{C}_{3}\right), 7.08(1 \mathrm{H}$, br s, H-2), $7.27(1 \mathrm{H}, \mathrm{dd}, J=1.1$ and $8.4 \mathrm{~Hz}, \mathrm{H}-7)$, 7.64 (1H, br s, H-4), 7.67 (1H, d, $J=8.4$ Hz, H-6), 7.81 (1H, br d, $J=8.4$ Hz, H-5), 11.99 (1H, s, -OH), and $12.10(1 \mathrm{H}, \mathrm{s},-\mathrm{OH}) ;{ }^{13} \mathrm{C}-\mathrm{NMR}\left(\mathrm{CDCl}_{3}\right) \delta: 22.3\left(\mathrm{CH}_{3}\right), 113.8(\mathrm{C}-12), 115.9(\mathrm{C}-13), 119.9(\mathrm{C}-7)$, 121.4 (C-4), 124.4 (C-5), 133.3 (C-14), 136.9 (C-6), 149. 3 (C-3), 162.4 (C-1), 162.7 (C-8), 181.9 (C$10)$, and 192.5 (C-9).

Emodin (4): Fine orange needles, m.p. $263-265^{\circ} \mathrm{C}$ (lit.[11] m.p. 264-265 ${ }^{\circ} \mathrm{C}$ ); EI-MS: $\mathrm{m} / z 270$ [M] $]^{+}$; ${ }^{1} \mathrm{H}-\mathrm{NMR}\left(2: 1 \mathrm{CDCl}_{3}+\mathrm{MeOH}-d_{4},\right) \delta: 2.44(3 \mathrm{H}, \mathrm{s}, \mathrm{CH} 3), 6.58(1 \mathrm{H}, \mathrm{d}, J=2.2 \mathrm{~Hz}, \mathrm{H}-7), 7.06(1 \mathrm{H}, \mathrm{s}, \mathrm{H}-$ 2), $7.21(1 \mathrm{H}, \mathrm{d}, J=2.5 \mathrm{~Hz}, \mathrm{H}-5)$, and $7.56\left(1 \mathrm{H}\right.$, br s, H-4); ${ }^{13} \mathrm{C}-\mathrm{NMR}\left(2: 1 \mathrm{CDCl}_{3}-d_{1}+\mathrm{MeOH}-d_{4},\right) \delta$ : $20.9\left(-\underline{\mathrm{CH}}_{3}\right), 107.6$ (C-7), 108.7 (C-5), 109.0 (C-12), 113.1 (s, C-13), 120.3 (C-4), 123.6 (C-2), 132.7 (C-14), 134.8 (C-11), 147.5 (C-3), 161.6 (C-1), 164.7 (C-8), 165. 6 (C-6), 181.9 (C-10), and 189.8 (C-9).

Methoxyemodin (Physcion) (5): Orange needles, m.p. 210-212 ${ }^{\circ} \mathrm{C}$ (lit. [18] 207 ${ }^{\circ} \mathrm{C}$ ); EI-MS: $\mathrm{m} / z 284$ $[\mathrm{M}]^{+} ;{ }^{1} \mathrm{H}-\mathrm{NMR}\left(\mathrm{CDCl}_{3}\right) \delta: 2.45\left(3 \mathrm{H}, \mathrm{s}, \mathrm{CH}_{3}\right), 3.50\left(3 \mathrm{H}, \mathrm{s},-\mathrm{OC}_{3}\right), 6.69(1 \mathrm{H}, \mathrm{d}, J=2.6 \mathrm{~Hz}, \mathrm{H}-7), 7.08$ $(1 \mathrm{H}$, br s, H-2), $7.36(1 \mathrm{H}, \mathrm{d}, J=2.6 \mathrm{~Hz}, \mathrm{H}-5), 7.62(1 \mathrm{H}$, br s, H-4), $12.10(1 \mathrm{H}, \mathrm{s},-\mathrm{OH})$, and $12.31(1 \mathrm{H}$, 
s, -OH $) ;{ }^{13} \mathrm{C}-\mathrm{NMR}\left(\mathrm{CDCl}_{3}\right) \delta: 22.2\left(\underline{\mathrm{CH}}_{3}\right), 56.1\left(-\mathrm{OCH}_{3}\right), 106.8(\mathrm{C}-7), 108.2(\mathrm{C}-5), 113.7(\mathrm{C}-12$ and $\mathrm{C}-$ 13), 121.3 (C-4), 124.5 (C-2), 133.3 (C-14), 135.3 (C-11), 148.5 (C-3), 162.5 (C-8), 165.2 (C-1), 166.6 (C-6), 182.0 (C-10), and 190.8 (C-9).

Sesamin (6): Colorless prisms, m.p. 127-129 ${ }^{\circ}$; EI-MS: $m / z 354[\mathrm{M}]^{+}, 323,203,161,149,135,103$; ${ }^{1} \mathrm{H}-\mathrm{NMR}\left(\mathrm{CDCl}_{3}\right)$ 8: $3.04\left(2 \mathrm{H}, \mathrm{m}, \mathrm{H}-8\right.$ and $\mathrm{H}-8$ '), $3.84\left(2 \mathrm{H}, \mathrm{m}, \mathrm{H}_{\mathrm{b}}-9\right.$ and $\left.\mathrm{H}_{\mathrm{b}}-9^{\prime}\right), 4.23\left(2 \mathrm{H}, \mathrm{m}, \mathrm{H}_{\mathrm{a}}-9\right.$ and $\left.\mathrm{H}_{\mathrm{a}}-9^{\prime}\right), 4.71\left(2 \mathrm{H}, \mathrm{m}, \mathrm{H}-7\right.$ and $\left.\mathrm{H}-7^{\prime}\right), 5.92$ [4H, s, (-O-C $\left.\left.\underline{\mathrm{H}}_{2}-\mathrm{O}-\right)_{2}\right], 6.76-6.84(6 \mathrm{H}, \mathrm{m}$, aromatic protons);

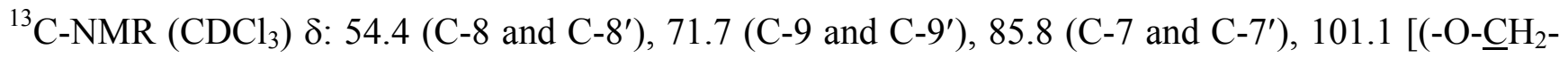
O-) 2 ], 106.5 (C-6 and C-6'), 108.2 (C-3 and C-3'), 119.4 (C-2 and C-2'), 135.1 (C-1 and C-1'), 147.1 (C-4 and C-4'), and 148.0 (C-5 and C-5').

\section{References}

1. Purseglove, J. W. “Tropical crops, Dicotyledons", $3^{\text {rd }}$ ed.; Wiley: New York, 1974.

2. Fouad, M. A. A. Pharmacognostical study of Glossostemon bruguieri (Desf.) growing in Egypt. Thesis, Faculty of Pharmacy, Cairo University, Cairo, Egypt, 1989.

3. Ibn Sina, A. "El-Kanoon Fil-Tebb”, III; El-Halaby and Co. for Publishing and Distribution: Cairo, Egypt, 1923.

4. El-Kiey, M. A.; Hashem, F. M. A Pharmacognostical study of Egyptian Moghat. Proc. Pharm. Soc. Egypt, 1957, 39, 12.

5. Amin, E. S.; Olfat, A. The mucilage of the roots of Glossestemon bruguieri (Desf.), Carbohyd. Res., 1968, 7, 12-16.

6. Karawya, M. S.; Balbaa, S. I.; Afifi, S. A. Investigation of the carbohydrate contents of certain mucilaginous plants. Planta Med., 1971, 20, 14-23.

7. Amin, E. S.; Awad, O.; Abdel Samad, M.; Iskander, M. N. Isolation of estrone from Moghat roots and from pollen grains of Egyptian date palm. Phytochemistry, 1969, 8, 295-297.

8. Afifi, S. A. A pharmacognostical study of certain mucilage-containing medicinal plants growing in Egypt. Thesis, Faculty of Pharmacy, Cairo University, Cairo, Egypt, 1969.

9. Komissarenko, N. F.; Derkach, A. I.; Sheremet, I. P.; Kovalev, I. P.,; Gordienko, V. G.; Pakaln, D. A. Flavonoids from the aerial parts of Stachys inflata. Khimiya Prirodnykh Soedinenii, 1978, 4, 521.

10. Hoang, T. H.; Ha, V. H.; Nguyen, H. K.; Pyne, S. G. Flavonoid with antioxidant effects extracted recently from leaves of Clerodendron fragrans. Tap Chi Duoc Hoc, 2000, 3, 10-12.

11. Kato, T.; Morita, Y. Anthraquinone components in Rumex acetosa L. Shoyakugaku Zasshi, 1987, 41, 67-74.

12. Francis, G. W.; Aksnes, D. W.; Holt, q. Assignment of the ${ }^{1} \mathrm{H}$ and ${ }^{13} \mathrm{C}$ NMR spectra of anthraquinone glycosides from Rhamnus frangula. Mag. Reson. Chem. 1998, 36, 769-772.

13. Greger, H.; Hofer, O. New unsymmetrically substituted tetrahydrofurofuran lignans from Artemisia absinthium. Tetrahedron 1980, 36, 3551-3558. 
14. Pelter, A.; Ward, R. S.; Rao, E.V.; Sastry, K. V. Revised structures for pluviatilol, methyl pluviatilol and xanthoxylol. Tetrahedron 1976, 32, 2783-2788.

15. Chari, V. M.; Ilyas, M.; Wagner, H.; Neszmelyi, A.; Chen, F.-C.; Chen, L.; Lin, y.-C.; Lin, Y.-M. ${ }^{13} \mathrm{C}-\mathrm{NMR}$ spectroscopy of biflavonoids. Phytochemistry 1977, 16, 1273-1378.

16. Wagner H.; Chari V. M.; Sonnenbichler J. ${ }^{13} \mathrm{C}$-NMR-spektren natürlich vorkommender flavonoide. Tetrahedron Lett. 1976, 1799-1802.

17. Nakano, D.; Itoh, C.; Takaoka, M.; Kiso, Y.; Tanaka, T.; Matsumura, Y. Antihypertensive effect of sesamin. IV. Inhibition of vascular superoxide production by sesamin. Biol. Pharm. Bull. 2002, 25, 1247-1249.

18. Thomson R. H. "Naturally Occurring Quinones" $2^{\text {nd }}$ Edition; Academic Press: New York, 1971.

Sample Availability: Available from the author.

(C) 2003 by MDPI (http://www.mdpi.org). Reproduction is permitted for noncommercial purposes. 